ISSN 1963 - 0762

\title{
DISIPLIN KERJA PEGAWAI PEMERINTAH KECAMATAN
}

\author{
Kaja \\ Fakultas Ilmu Sosial dan Ilmu Politik Universitas Kapuas \\ Gmail :Kajaunka@gmail.com
}

\begin{abstract}
Abstrak : Disiplin Kerja Pegawai di Kantor Camat Kecamatan Sungai Tebelian Kabupaten Sintang. Hasil penelitian menunjukan bahwa pembinaan pegawai di Kantor Camat Sungai Tebelian diatur berdasarkan ketentuan perundang-undangan atau Peraturan Pemerintah yang mengatur mengenai kewajiban, larangan, hukuman disiplin. Pola pembinaan PNS diperlukan ketegasan dan pendekatan yang mengacu pada peraturan yang ada, Pembinaan disiplin pegawai Kantor Camat Sungai Tebelian dilakukan sesuai dengan Peraturan Pemerintah Nomor 53 Tahun 2010 tentang disiplin Pegawai Negeri Sipil. Peraturan tersebut mulai diterapkan dan hampir seluruh PNS sudah menerapkan penegakan displin pegawai. Peraturan itu berlaku untuk semua PNS dalam pembinaan pegawai paling tidak diarahkan dalam pertemuan masing-masing seksi sudah diintruksikan, secara bergiliran semua seksi melakukan pembinaan kepada pegawai/stafnya, sekaligus untuk menilai tingkat disiplin para pegawai melalui pengarahan, bimbingan, pengembangan pegawai melalui pendidikan dan latihan. Selain itu, juga mengusulkan promosi jabatan kepada pegawai yang di anggap mampu bekerja dan mempunyai disiplin kerja yang baik untuk menduduki jabatan yang lebih tinggi. Manfaat penghargaan yang di berikan kepada pegawai agar termotivasi dalam menjalankan tugasnya dengan baik.
\end{abstract}

Kata Kunci : Disiplin, Kerja Pegawai.

Dalam Undang-Undang Nomor 43 Tahun 1999 tentang pokok-pokok kepegawaian di katakan bahwa untuk menduduki suatu jabatan dilingkungan suatu organisasi kerja yang diselenggarakan oleh pemerintah, seorang pegawai negeri harus memenuhi persyaratan atau ketentuan-ketentuan. Ketentuan-ketentuan itu dibedakan antara ketentuan umum dalam arti berlaku bagi semua jabatan pada semua instansi atau lembaga Pemerintahan dan ketentuanketentuan khusus yang berbeda-beda antara suatu jabatan dengan jabatan yang lain sesuai dengan jenis dan sifat pekerjaan dilingkungan masingmasing. Kedisiplinan adalah kesadaran dan kesediaan seseorang menaati semua peraturan organisasi kerja dan norma-norma sosial yang berlaku (Hasibuan, 2002:193). Setiap organisasi pada umumnya menginginkan agar para pegawai yang bekerja dapat mematuhi tata tertib atau peraturan yang telah ditetapkan. Dengan ditetapkannya peraturan baik tertulis maupun tidak tertulis, agar para pegawai dapat melaksanakan sikap disiplin dalam bekerja sehingga produktivitasnya pun meningkat. Disiplin kerja dapat didefinisikan sebagai suatu sikap menghormati, menghargai, patuh dan taat terhadap peraturan-peraturan yang berlaku, baik yang tertulis maupun tidak tertulis serta sanggup menjalankannya dan tidak mengelak untuk menerima sanksi-sanksinya apabila ia melanggar tugas dan wewenang yang diberikan kepadanya (Sastrohadiwiryo, 2001 : 291) Pendapat lain merumuskan bahwa disiplin kerja adalah kesadaran dan kesediaan seseorang menaati semua peraturan dan norma-norma sosial yang berlaku.

Kesadaran adalah sikap seseorang yang secara sukarela menaati semua peraturan dan sadar akan tugas dan tanggung jawabnya, kesediaan adalah suatu sikap, tingkah laku, dan peraturan organisasi kerja, baik yang tertulis maupun tidak. (Hasibuan, 2002 : 193) Berdasarkan dua pendapat diatas maka dapat disimpulkan bahwa disiplin kerja adalah sikap pada pegawai untuk berperilaku sesuai dengan peraturan yang telah ditetapkan dimana dia bekerja. Sedangkan tibdakan disiplin itu sendiri adalah pengurangan yang dipaksakan oleh 
pimpinan terhadap imbalan yang diberikan oleh organisasi karena adanya suatu kasus tertentu. Tindakan disiplin ini tidak termasuk pemberhentian sementara atau penurunan jumlah tenaga kerja yang disebabkan oleh kejadian-kejadian perilaku khusus dari pegawai yang menyebabkan rendahnya produktivitas atau pelanggaran-pelanggaran aturan-aturan instansi.

Disiplin yang mantap pada hakekatnya akan tumbuh dan terpancar dari hasil kesadaran manusia. Disiplin yang tidak bersumber dari hati nurani manusia akan menghasilkan disiplin yang lemahdan tidak bertahan lama. Disiplin akan tumbuh dan dapat dibina melalui latihan, pendidikan atau penanaman kebiasaan dengan keteladanan-keteladanan tertentu, yang harus dimulai sejak ada dalam lingkungan keluarga, mulai pada masa kanak-kanak dan terus tumbuh berkembang dan menjadikannya bentuk disiplin yang semakin kuat (Prijodarminto, 1994:25). Sejalan dengan pendapat tersebut di atas, Handoko (1998:208), mengatakan disiplin kerja dapat dibedakan menjadi 3 (tiga) sebagai berikut : 1. Disiplin Preventif, merupakan kegiatan yang dilakukan dengan maksud untuk mendorong para pegawai agar secar sadar mentaati berbagai standart dan aturan, sehingga dapat dicegah berbagai penyelewengan atau pelanggaran. Lebih utama dalam hal ini adalah dapat ditumbuhkan " Self Dicipline" pada setiap pegawai tanpa kecuali. Manajemen mempunyai tanggung jawab untuk menciptakan suatu iklim disiplin preventif dimana berbagai standar diketahui dan dipahami. Untuk memungkinkan iklim yang penuh disiplin kerja tanpa paksaan tersebut perlu kiranya standart itu sendiri bagi setiap pegawai, dengan demikian dicegah kemungkinan-kemungkinan timbulnya pelanggaranpelanggaran atau penyimpangan dari standart yang ditentukan. 2. Disiplin Korektif, disiplin ini merupakan kegiatan yang diambil untuk menangani pelanggaran yang telah terjadi terhadap aturan-aturan dan mencoba untuk menghindari pelanggaran lebih lanjut. Kegiatan korektif ini dapat berupa suatu bentuk hukuman dan disebut tindakan pendisiplinan (disciplinary action) 3 . Disiplin Progresif, Disiplin ini berarti memberikan hukuman-hukuman yang lebih berat terhadap pelanggaran-pelanggaran yang berulang. Tujuannya adalah memberikan kesempatan kepada pegawai untuk mengambil tindakan korektif sebelum hukuman-hukuman yang lebih serius dilaksanakan. Disiplin progresif juga memungkinkan manajemen untuk membantu pegawai memperbaiki kesalahan.

Menurut Prijodarminto, (1994 : 25) disiplin dapat dibedakan berdasarkan tingkatannya, yaitu: 1. Disiplin Pribadi. Disiplin pribadi sebagai perwujudan disiplin yang lahir dari kepatuhan atas aturan-aturan yang mengatur perilaku individu. 2. Disiplin Kelompok. 3. Disiplin kelompok sebagai perwujudan yang lahir dari sikap taat, patuh terhadap aturan-aturan (hukum) dan normanorma yang berlaku pada kelompok atau bidang-bidang kehidupan manusia.

Disiplin Nasional. Disiplin nasional yakni wujud disiplin yang lahir dari sikap patuh yang ditunjukkan oleh seluruh lapisan masyarakat terhadap aturan-aturan, nilai yang belaku secara nasional. Dalam setiap oragnisasi atau organisasi kerja yang diinginkan adalah jenis disiplin preventif yang timbul dari diri sendiri atas dasar kerelaan dan kesadaran. Akan tetapi dalam kenyataan selalu mengatakan bahwa disiplin itu lebih banyak disebabkan adanya paksaan dari luar dan hak-hak pegawai sudah menjadi alat pengenalan yang tepat kepada disiplin pegawai, karena hak-hak pegawai seringkali merupakan masalah dalam kasus-kasus disiplin pegawai. Demikian juga dalam penelitian ini jenis-jenis disiplin kerja yang dikaji adalah disiplin preventif yang dilaksanakan untuk mendorong pegawai agar mengikuti aturan yang telah ditetapkan.

Disiplin kerja dapat didefinisikan sebagai suatu sikap menghormati, menghargai, patuh dan taat terhadap peraturan-peraturan yang berlaku, baik yang tertulis maupun tidak tertulis serta sanggup menjalankannya dan tidak mengelak 
untuk menerima sanksi-sanksinya apabila ia melanggar tugas dan wewenang yang diberikan kepadanya. Menurut Sastrohadiwiryo, (2001:291) bahwa "disiplin kerja adalah kesadaran dan kesediaan seseorang menaati semua peraturan dan norma-norma sosial yang berlaku". Selain itu menurut Hasibuan, (2002:193) Kesadaran adalah "sikap seseorang yang secara sukarela menaati semua peraturan dan sadar akan tugas dan tanggung jawabnya, kesediaan adalah suatu sikap, tingkah laku, dan peraturan organisasi kerja, baik yang tertulis maupun tidak". Berdasarkan dua pendapat diatas maka dapat disimpulkan bahwa disiplin kerja adalah sikap pada pegawai untuk berperilaku sesuai dengan peraturan yang telah ditetapkan dimana dia bekerja. Sedangkan tindakan disiplin itu sendiri adalah pengurangan yang dipaksakan oleh pimpinan terhadap imbalan yang diberikan oleh organisasi karena adanya suatu kasus tertentu. Tindakan disiplin ini tidak termasuk pemberhentian sementara atau penurunan jumlah tenaga kerja yang disebabkan oleh kejadiankejadian perilaku khusus dari pegawai yang menyebabkan rendahnya produktivitas atau pelanggaran-pelanggaran aturan-aturan instansi.

Disiplin yang mantap pada hakekatnya akan tumbuh dan terpancar dari hasil kesadaran manusia. Disiplin yang tidak bersumber dari hati nurani manusia akan menghasilkan disiplin yang lemah dan tidak bertahan lama. Disiplin akan tumbuh dan dapat dibina melalui latihan, pendidikan atau penanaman kebiasaan dengan keteladanan-keteladanan tertentu, yang harus dimulai sejak ada dalam lingkungan keluarga, mulai pada masa kanak-kanak dan terus tumbuh berkembang dan menjadikannya bentuk disiplin yang semakin kuat. Menurut Prijodarminto, (1994 : 25) bahwa disiplin dapat dibedakan berdasarkan tingkatannya, yaitu : 1. Disiplin pribadi, sebagai perwujudan disiplin yang lahir dari kepatuhan atas aturan-aturan yang mengatur perilaku individu. 2. Disiplin Kelompok adalah sebagai perwujudan yang lahir dari sikap taat, patuh terhadap aturan-aturan (hukum) dan norma- norma yang berlaku pada kelompok atau bidangbidang kehidupan manusia. 3. Disiplin nasional, yakni wujud disiplin yang lahir dari sikap patuh yang ditunjukkan oleh seluruh lapisan masyarakat terhadap aturan-aturan, nilai yang belaku secara nasional. Dalam setiap oragnisasi atau organisasi kerja yang diinginkan adalah jenis disiplin preventif yang timbul dari diri sendiri atas dasar kerelaan dan kesadaran. Akan tetapi dalam kenyataan selalu mengatakan bahwa disiplin itu lebih banyak disebabkan adanya paksaan dari luar dan hakhak pegawai sudah menjadi alat pengenalan yang tepat kepada disiplin pegawai, karena hak-hak pegawai seringkali merupakan masalah dalam kasus-kasus disiplin pegawai. Demikian juga dalam penelitian ini jenis-jenis disiplin kerja yang dikaji adalah disiplin preventif yang dilaksanakan untuk mendorong pegawai agar mengikuti aturan yang telah ditetapkan.

\section{Penegakan Aturan Disiplin}

Penegasan peraturan disiplin pegawai diatur dalam peraturan pemerintah Nomor 30 Tahun 1980 tentang peraturan disiplin pegawai . Dalam peraturan disiplin PNS diatur ketentuan-ketentuan mengenai:(1). Kewajiban, (2). Larangan; (3). Hukuman disiplin; (4). Pejabat yang berwenang menghukum; (5). Penjatuhan hukuman disiplin; (6). Keberatan atas hukuman disiplin; (7).Berlakunya keputusan hukuman disiplin. Menurut Depdikbud (1988:208) disiplin juga dapat berarti "tata tertib, ketaatan, atau kepatuhan kepada peraturan tata tertib". Dalam bahasa Indonesia istilah disiplin kerap kali terkait dan menyatu dengan istilah tata tertib dan ketertiban. Dengan demikian, kedisiplinan halhal yang berkaitan dengan ketaatan atau kepatuhan seseorang terhadap peraturan atau tata tertib yang berlaku. Sedangkan Menurut Amatembun (1974:6). kedisiplinan adalah "keadaan tertib dimana orang yang tergabung dalam organisasi tunduk pada peraturan yang telah ada dengan senang hati”. Setiap organisasi pada umumnya menginginkan agar para pegawai yang bekerja dapat mematuhi tata tertib atau 
peraturan yang telah ditetapkan. Dengan ditetapkannya peraturan baik tertulis maupun tidak tertulis, diharapkan agar para pegawai dapat melaksanakan sikap disiplin dalam bekerja sehingga produktivitasnya pun meningkat. Menurut Sastrohadiwiryo, (2002 : 291) bahwa "disiplin kerja sebagai suatu sikap menghormati, menghargai, patuh dan taat terhadap peraturanperaturan yang berlaku, baik yang tertulis maupun tidak tertulis serta sanggup menjalankannya dan tidak mengelak untuk menerima sanksi-sanksinya apabila ia melanggar tugas dan wewenang yang diberikan kepadanya". Sedangkan menurut Hasibuan, (2002 : 193) bahwa "disiplin kerja adalah kesadaran dan kesediaan seseorang menaati semua peraturan dan norma-norma sosial yang berlaku. Kesadaran adalah sikap seseorang yang secara sukarela menaati semua peraturan dan sadar akan tugas dan tanggung jawabnya, kesediaan adalah suatu sikap, tingkah laku, dan peraturan organisasi kerja, baik yang tertulis maupun tidak". Tindakan disiplin ini tidak termasuk pemberhentian sementara atau sanksi disebabkan oleh kejadian-kejadian perilaku khusus dari pegawai yang menyebabkan rendahnya produktivitas atau pelanggaranpelanggaran aturan-aturan instansi.

Kedisiplinan kerja pegawai memiliki fungsi tertentu. Menurut Meichati (1979:7) "kedisiplinan kerja pegawai berfungsi sebagai alat pendidikan dan alat menyesuaikan dalam membentuk sikap dan tingkah laku yang baik, yang nantinya dapat digunakan juga dalam lingkungan keluarga maupun lingkungan masyarakat". Kedisiplinan sebagai alat pendidikan yang dimaksud adalah suatu tindakan, perbutan yang dengan sengaja diterapkan untuk kepentingan pendidikan kerja pegawai. Tindakan atau perbuatan tersebut dapat berupa perintah, nasehat, larangan, harapan, dan hukuman atau sanksi. Disiplin itu lahir, dan berkembang dari sikap seseorang di dalam sistem nilai budaya yang telah ada di dalam masyarakat. Terdapat unsur pokok yang membentuk disiplin, pertama sikap yang telah ada pada diri manusia dan sistem nilai budaya yang ada di dalam masyarakat. Sikap atau attitude tadi merupakan unsur yang hidup di dalam jiwa manusia yang harus mampu bereaksi terhadap lingkungannya, dapat berupa tingkah laku atau pemikiran. Sedangkan sistem nilai budaya merupakan bagian dari budaya yang berfungsi sebagai petunjuk atau pedoman bagi kelakuan manusia. Perpaduan antara sikap dengan sistem nilai budaya yang menjadi pengarah dan pedoman tadi mewujudkan sikap mental berupa perbuatan atau tingkah laku. Unsur tersebut membentuk suatu pola kepribadian yang menunjukkan perilaku disiplin atau tidak disiplin.

\section{Keteladanan Pimpinan}

Menurut Wahjosumidjo (dalam Prijadarminto,1994:64) memberikan beberapa petunjuk yang dapat dilakukan oleh pimpinan dalam meningkatkan disiplin antara lain: 1. Memberikan informasi yang lengkap terhadap bawahan tentang peraturan dan hukuman bagi yang melanggar. 2. Mengelola disiplin secara tepat dan konsisten. 3. Memberikan peringatan yang cukup sebelum memberikan hukuman. 4 . Mencari bukti sebelum menjatuhkan teguran dan hukuman. 4. Selalu memelihara harga diri kepala organisasi 5. Menggunakan segala macam hukuman secara tepat. 6 . Secara pribadi memberikan peringatan tertentu pada bawahan. Dengan demikian Seorang pemimpin harus mampu menumbuhkan displin, terutama disiplin diri. Dalam kaitan ini, kepala organisasi harus mampu membantu para pegawai mengembangkan pola dan meningkatkan standar perilakunya, serta menggunakan pelaksanaan aturan sebagai alat untuk menegakkan disiplin. Peningkatan profesionalisme pegawai perlu dimulai dengan sikap demokratis. Menurut Saksono (1997:45) mengemukakan bahwa "pemimpin dalam mendisiplinkan seseorang hendaknya jangan terlalu emosi, jangan menyerang pribadi, spesifik, tepat waktu, konsisten, jangan mengancam, bersikap adil, dan ingat bahwa pendisiplinan tidak untuk memperkuat perilaku yang kurang baik.

Dengan keteladanan yang ia tunjukkan, 
seorang tokoh dengan mudah mempengaruhi banyak orang untuk mewujudkan suatu tujuan, tentu saja untuk tujuan yang baik. Demikian pula halnya keteladanan bagi seorang pimpinan, tidak saja harus ditunjukkan ketika berada kerja pegawai atau di lingkungan organisasi. Sosok pimpinan dan profesinya melekat di mana saja mereka berada, sehingga kata pimpinan selalu dipergunakan sebagai identitas, baik ketika pimpinan tersebut melakukan aktivitas yang berkaitan dengan dunia pendidikan, maupun kegiatan yang jauh dari ranah pendidikan. Kepemimpinan dibutuhkan oleh manusia karena adanya suatu keterbatasan dan kelebihan-kelebihan tertentu pada manusia. Maksudnya di satu pihak manusia terbatas kemampuannya untuk memimpin, sementara dilain pihak ada orang yang memiliki kelebihan kemampuan untuk memimpin. Dari keadaan inilah maka timbul akan kebutuhan akan seorang pemimpin. Pemimpin merupakan salah satu intisari manajemen, sumber daya pokok dan titik sentral dari setiap aktivitas yang terjadi dalam suatu organisasi.

Kreativitas seorang pemimpin dalam menjalankan wewenangnya, sangat menentukan keberhasilan organisasi yang hendak di capai. Kepemimpinan merupakan faktor yang sangat penting dalam mempengaruhi prestasi organisasi, karena kepemimpinan merupakan aktivitas utama di mana, melalui kegiatan kepemimpinan tujuan organisasi dapat di capai. Menurut Louis A. Allen (dalam Nawawi, 2001:225) bahwa setiap organisasi kerja termasuk juga lembaga-lembaga pemerintah, setiap pimpinannya berkewajiban menggerakkan dan mengarahkan semua personal atau pegawai agar mewujudkan volume atau beban kerja masingmasing. Sejalan dengan pendapat itu Nawawi $H$. (2001:225) mengatakan sebagai berikut: "Kepemimpinan adalah tindakan atau perbuatan diantara perseorangan dan kelompok yang menyebabkan baik orang seorang maupun kelompok bergerak kearah tujuan tertentu. Kepemimpinan tampak dalam proses dimana seseorang mengarahkan, membimbing, mempengaruhi, dan atau mengawasi pikiranpikiran, perasaan atau tingkah laku orang lain."

Kepemimpinan dapat dilihat sebagai proses kekuatan dibalik sukses suatu organisasi. Menurut Toha (1993:1) mengatakan suatu "organisasi akan berhasil atau gagal ditentukan oleh kepemimpinan itu sendiri, karena begitu pentingnya peranan kepemimpinan dalam suatu organisasi mencapai suatu tujuan organisasi yang telah ditetapkan". Menurut Siagian (1983:24) mengartikan kepemimpinan sebagai kemampuan dan keterampilan seseorang yang menduduki jabatan sebagai pemimpin satuan kerja untuk mempengaruhi perilaku orang lain terutama bawahannya, untuk berpikir dan bertindak sedemikian rupa sehingga melalui perilaku yang positif ia memberikan sumbangsih nyata dalam pencapaian tujuan organisasi. Berdasarkan pengertian di atas menggambarkan bahwa kepemimpinan adalah merupakan kegiatan pemimpin untuk mempengaruhi orang lain atau bawahannya dalam berbagai situasi dan kondisi agar bersedia dengan ikhlas baik secara bersama-sama atau secara perorangan, melaksanakan tanggung jawabnya terhadap tugas-tugas yang dibebankan kepadanya dalam rangka pencapaian tujuan yang diinginkan. Dengan demikian kepemimpinan merupakan sebuah proses memberi arti (pengarahan yang berarti) terhadap usaha kolektif, dan yang mengakibatkan kesediaan untuk melakukan usaha yang diinginkan untuk mecapai sasaran.

\section{Rewarding}

Menurut Gito Sudarmo (2000:12) “ Reward diberikan atas dasar prestasi, sehingga bukan merupakan hak pegawai yang biasa menerima meskipun tidak memiliki prestasi". Pemberian reward yang memadai akan memotivasi pagawai lain untuk berbuat serupa dan sekaligus menjadi sarana terjadi kompetisi sehat diantara para pegawai, tanpa dilandasi oleh perasaan dan sikap asal bapak senang. 
Menurut Yulk (1994:112) bahwa" Rewarding adalah sebuah kategori perilaku yang menyangkut pemberian manfaat-manfaat yang berwujud kepada seseorang bagi kinerja yang efektif, sehingga keberhasilan yang signifikan dan bantuan yang bermanfaat". Sasaran dari pemberian penghargaan adalah untuk meningkatkan usaha para pegawai dalam pelaksanaan tugasnya. Memberi penghargaan bertindak sebagai suatu fungsi menjernihkan dengan menunjukkan prioritas-prioritas relatif diantara berbagai aspek kinerja.

\section{Punishment}

Menurut Sastrohadiwiryo (2001:293) tujuan utama mengadakan sanksi disiplin kerja bagi pegawai yang melanggar norma-norma organisasi kerja adalah memperbaiki dan mendidik para pegawai yang melakukan pelanggaran disiplin. Sanksi atas pelanggaran disiplin yang dijatuhkan haruslah setimpal dengan pelanggaran disiplin yang dilakukan sehingga secara adil dapat diterima. Pada umumnya sebagai pegangan menajer meskipun tidak mutlak, tingkat dan jenis sanksi disiplin kerja terdiri atas sanksi disiplin berat, sanksi disiplin sedang, dan sanksi disiplin ringan. Pada dasarnya aturan itu dibuat untuk membentuk manusia yang teratur, damai, taat, dan faham terhadap kepentingan orang banyak, namun karena yang diaturnya manusia dengan berbagai latar belakang dan kepentingan yang berbeda, maka dalam menafsirkan aturan itu akan terobsesi oleh kepentingan dirinya. Menurut Pinjadarminto (1994:77) bahwa "Tata tertib organisasi biasanya berisi hal-hal positif yang harus dilakukan oleh pegawai. Sisi lainnya berisi sanksi/hukuman bagi yang melanggar tata tertib tersebut. Ancaman sanksi/hukuman sangat penting karena dapat memberi dorongan dan kekutan bagi pegawai untuk menaati dan mematuhinya. Tanpa ancaman hukuman/sanksi, dorongan ketaatan dan kepatuhan dapat diperlemah". Secara umum berdasarkan peraturan kepegawaian, hukuman disiplin adalah hukuman yang dijatuhkan terhadap seorang Pegawai. Adapun tingkat hukuman disiplin adalah (1).Hukuman disiplin ringan, (2). Hukuman disiplin sedang, dan (3) Hukuman disiplin berat. Penerapan hukuman tersebut sesuai dengan Peraturan Pemerintah Nomor 53 tahun 2010 tentang disiplin Pegawai Negeri Sipil.

Setiap hukuman disiplin dijatuhkan oleh pejabat yang berwenang menghukum sesuai tata cara tersebut dalam Surat Edaran Kepala Badan Administrasi Kepegawaian Negara Nomor 23/SE/1980 tanggal 30 Oktober 1980 tentang peraturan disiplin pegawai. Tujuan hukuman disiplin adalah untuk memperbaiki dan mendidik PNS yang melakukan pelanggaran disiplin, oleh sebab itu setiap pejabat yang berwenang menghukum sebelum menjatuhkan hukuman disiplin harus memeriksa lebih dahulu PNS yang melakukan pelanggaran disiplin. Terhadap PNS yang disangka melakukan pelanggaran disiplin diadakan pemeriksaan. Tujuan pemeriksaan adalah untuk mengetahui apakah PNS yang bersangkutan benar telah melakukan pelanggaran disiplin. Pemeriksaan juga bertujuan untuk mengetahui latar belakang serta hal-hal yang mendorong pelanggaran disiplin tersebut. Pemeriksaan dilaksanakan sendiri oleh pejabat yang berwenang menghukum atau pejabat lain yang ditunjuk. Apabila pejabat pada waktu memeriksa PNS yang disangka melakukan pelanggaran disiplin berpendapat, bahwa berdasarkan hasil pemeriksaannya hukuman disiplin yang wajar dijatuhkan adalah di luar wewenangnya, maka pejabat tersebut wajib melaporkan hal itu kepada pejabat yang berwenang menghukum yang lebih tinggi melalui saluran hirarkhi. Laporan tersebut disertai dengan hasil-hasil pemeriksaan dan bahan-bahan lain yang diperlukan. Pejabat yang berwenang menghukum yang lebih tinggi wajib memperhatikan dan mengambil keputusan atas laporan itu.

Sebelum menetapkan keputusan penjatuhan hukuman disiplin, pejabat yang berwenang menghukum wajib mempelajari 
dengan saksama laporan hasil pemeriksaan pelanggaran disiplin. Hukuman disiplin harus setimpal dengan pelanggaran disiplin yang dilakukan dan harus dapat diterima dengan rasa keadilan. Kepada Pegawai yang berdasarkan hasil pemeriksaan ternyata melakukan beberapa pelanggaran disiplin, terhadapnya hanya dapat dijatuhi satu jenis hukuman disiplin. Kepada Pegawai yang pernah dijatuhi hukuman disiplin yang kemudian melakukan pelanggaran disiplin yang sifatnya sama, terhadapnya dijatuhi hukuman disiplin yang lebih berat dari hukuman disiplin terakhir yang pernah dijatuhkan kepadanya. Hukuman disiplin yang berupa tegoran lisan disampaikan secara lisan oleh pejabat yang berwenang menghukum. Hukuman disiplin berupa tegoran tertulis, "pernyataan tidak puas secara tertulis, penundaan kenaikan gaji berkala, penurunan gaji, penundaan kenaikan pangkat, penurunan pangkat, pembebasan dari jabatan, pemberhentian dengan hormat tidak atas permintaan sendiri sebagai Pegawai, dan pemberhentian tidak dengan hormat sebagai Pegawai ditetapkan dengan surat keputusan pejabat yang berwenang menghukum.

Pegawai yang dijatuhi hukuman disiplin dipanggil untuk menerima keputusan hukuman disiplin pada waktu dan tempat yang ditentukan. Keputusan hukuman disiplin disampaikan secara langsung oleh pejabat yang berwenang menghukum kepada Pegawai yang dijatuhi hukuman disiplin. Penyampaian keputusan hukuman disiplin tersebut dapat dihadiri pegawai lain, dengan ketentuan bahwa pangkat dan jabatan pegawai yang hadir tidak boleh lebih rendah dari pangkat dan jabatan Pegawai yang dijatuhi hukuman disiplin. Hukuman disiplin yang ditetapkan dengan keputusan Presiden disampaikan oleh pimpinan instansi tempat Pegawai yang dijatuhi hukuman disiplin bekerja. Pegawai yang dijatuhi hukuman disiplin dapat mengajukan keberatan atas keputusan hukuman disiplin, kecuali terhadap hukuman disiplin tingkat ringan dan hukuman disiplin berupa "pembebasan dari jabatan. Keberatan terhadap keputusan hukuman disiplin disampaikan secara tertulis kepada atasan pejabat yang berwenang menghukum, yaitu atasan langsung pejabat yang berwenang menghukum, melalui saluran hirarkhi selambat-lambatnya 14 (empat belas) hari terhitung mulai tanggal penyampaian keputusan hukuman disiplin.

Setiap atasan yang menerima keberatan terhadap hukuman disiplin wajib meneruskan keberatan tersebut kepada atasannya selambatlambatnya selama 3 (tiga) hari kerja sejak ia menerima surat pernyataan keberatan tersebut. Pejabat yang berwenang menghukum yang juga menerima pernyataan keberatan, meneruskannya kepada atasan pejabat yang berwenang menghukum, disertai catatancatatan yang dianggap perlu sehubungan keputusan hukuman disiplin yang ditetapkan olehnya, selambat-lambatnya 3 (tiga) hari kerja sejak ia menerima surat pernyataan keberatan tersebut. Hukuman disiplin berupa pembebasan dari jabatan berlaku mulai saat disampaikan, dan harus segera dilaksanakan. Apabila Pegawai yang dijatuhi hukuman disiplin tidak hadir pada waktu dan tempat yang ditentukan untuk penyampaian keputusan hukuman disiplin, maka hukuman disiplin berlaku mulai hari ke 30 (tiga puluh) terhitung mulai tanggal yang ditentukan untuk penyampaian keputusan hukuman disiplin tersebut. Hapusnya kewajiban menjalankan hukuman disiplin kewajiban untuk menjalankan hukuman disiplin dapat hapus karena Pegawai yang meninggal pada waktu sedang menjalani hukuman disiplin berupa penundaan kenaikan gaji berkala dan penurunan gaji, dan penurunan pangkat" dianggap telah selesai menjalani hukuman disiplin. Pegawai yang mencapai batas usia pensiun pada waktu sedang menjalani hukuman disiplin berupa penundaan kenaikan gaji berkala, penurunan gaji, dan penurunan pangkat dianggap telah selesai menjalani hukuman disiplin.

\section{METODE PENELITIAN}

Menurut Nawawi (2003: 63) "Metode deskriptif adalah sebagai prosedur pemecahan masalah yang diselidiki dengan 
menggambarkan/melukiskan keadaan subyek/ obyek penelitian (seseorang, lembaga, masyarakat dan lain-lain) pada saat sekarang berdasarkan fakta-fakta yang tampak atau sebagai adanya". Menurut Amirin (2000:118) bahwa "penelitian deskriptif menghasilkan penelitian yang tarafnya dalam memberikan penjelasan mengenai gejala yang diteliti paling rendah, sebab penelitian ini tidak berusaha untuk mengetahui (menjelaskan) sebab akibat, melainkan hanya sekedar menghasilkan keterangan yang menggambarkan ciri-ciri gejala saja." Pada saat ini penggunaan metode deskriptif dalam penelitian tidak hanya sekedar terbatas pada penemuan fakta seadanya, tetapi diiringi dengan analisis data secara kualitatif yaitu suatu penelitian yang mengumpulkan data dan fakta-fakta dengan tuntas dari orang-orang yang diamati. Penelitian ini merupakan sebagai usaha untuk merencanakan kemungkinankemungkinan tertentu secara luas tanpa menunjukkan secara pasti apa yang akan dikerjakan dalam hubungan dengan unsurnya masing-masing. Subjek Penelitian dalam penelitian ini adalah : Camat Kecamatan Sungai Tebelian, Kasi Pembinaan dan pengembangan pegawai Kantor Camat Sungai Tebelian, Pegawai Kantor Camat Sungai Tebelian. Alat pengumpulan data dalam penelitian ini adalah : Pedoman Wawancara, Pedoman Observasi, dokumentasi. Teknik Analisis Data Setelah keseluruhan data yang diperlukan terkumpul, maka pengolahan data dalam penelitian ini menggunakan teknik analisis kualitatif. Teknik analisis kualitatif yaitu setelah seluruh data terkumpul baik data primer maupun data sekunder, maka data tersebut dituangkan dalam pernyataan-pernyataan, kalimat-kalimat atau ungkapan-ungkapan berupa naratif, yang pada akhirnya dianalisis sesuai dengan tujuan penelitian. Selanjutnya akan ditarik suatu kesimpulan sebagai akhir dari analisis data. Adapun Lokasi Penelitian Penelitian ini dilakukan pada Kantor Camat Kecamatan Sungai Tebelian Kabupaten Sintang.

\section{HASIL PENELITIAN}

Peraturan Pemerintah Nomor 53 tahun 2010 tentang peraturan disiplin pegawai negeri. Peraturan tersebut mulai diterapkan dan hampir seluruh semua RRI sudah mulai di terapkan penegakan displin pegawai Kantor Camat Sungai Tebelian yang sifatnya PNS dan peraturan itu berlaku untuk semua pegawai Kantor Camat Sungai Tebelian. Selain itu halhal yang wajib bagi pegawai Kantor Camat Sungai Tebelian antara lain masuk kerja dan mentaati ketentuan jam kerja dari pukul 07.1515.15 wib, memberikan pelayanan sebaikbaiknya kepada masyarakat, membimbing bawahan untuk mengembangkan karir, mentaati peraturan kedinasan yang ditetapkan oleh pejabat yang berwenang dan mentaati perjanjian kerja yang telah ditandatangai oleh pegawai Kantor Camat Sungai Tebelian serta mentaati kode etik pegawai. Selain itu apabila melakukan kesalahan kembali perlu mendapatkan teguran tertulis yang di sampaikan pimpinan kepada stafnya, nah selama ini teguran secara tertulis itu ada temanteman yang mendapatkan, namun secara ril apa bila teguran itu sesuai dengan kesalahannya, mungkin teguran itu akan memotivasi pegawai untuk bekerja lebih baik dan membenahi dirinya.Pembinaan yang ada di Kantor Camat Sungai Tebelian memang belum maksimal, artinya pemberian pembinaan, hanya bersifat pengarahan, dalam bentuk rapat dan pengarahan dari pimpinan, hanya memberikan penegasan supaya dapat menjalan tugas dengan baik, mengisi absen, rutin menjalankan tugas. Dalam menjalankan tugasnya kemudian melakukan kelalaian perlu mendapat sanksi oleh pimpinan, sanksi itu dapat berupa lisan. Apabila melakukan kesalahan kembali perlu mendapatkan teguran tertulis yang di sampaikan pimpinan kepada stafnya, teguran itu sesuai dengan kesalahannya, mungkin teguran itu akan memotivasi pegawai untuk bekerja lebih baik dan membenahi dirinya. Oleh karena itu, pimpinan membuat kriteria penilaian 
berdasarkan pada aturan yang berlaku sehingga staf yang mempunyai pontensi, mempunyai prestasi, kemampuan yang bagus itu juga harus menjadi catatan, tetapi bagi pegawai yang tidak disiplin bekerja, kemudian kemampuan berkurang itu juga harus di tingkatkan dari segi sumber daya manusiaannya. Penegakan aturan disiplin sudah berjalan dengan baik sesuai tugas masing-masing, karyawan sudah memiliki komitmen dengan tugas masing-masing dan sudah dibentuk tim pemantau untuk penegakan disiplin yang di ketuai oleh Kepala sub bagian tata usaha dan anggotanya masing-masing kepala seksi yang bertugas memantau pegawai. Penegakan disiplin itu wajib dan merupakan keharusan, karena melayani publik oleh karena itu, penegakan aturan dalam bekerja merupakan salah satu usaha yang dilakukan dalam mendukung pelaksanaan pekerjaan yang efektif dan efisien. Selama ini masyarakat menginginkan penegakkan aturan menjadi kenyataan, dengan alasan masyarakat menginginkan pelayanan yang baik dari para pegawai secara optimal sesuai dengan peran, tugas dan tanggung jawabnya.

Kelalaian dalan menjalankan tugas perlu mendapat sanksi oleh pimpinan, sanksi itu dapat berupa lisan. Pegawai yang melakukan kesalahan kembali perlu mendapatkan teguran tertulis yang di sampaikan pimpinan kepada stafnya, teguran secara tertulis te sesuai dengan kesalahannya, mungkin teguran itu akan memotivasi pegawai untuk bekerja lebih baik dan membenahi dirinya. Kedisiplinan merupakan suatu kondisi yang tercipta dan terbentuk melalui proses dari serangkaian perilaku yang menunjukkan nilai-nilai ketaatan, kepatuhan, kesetiaan, keteraturan dan atau ketertiban. Oleh karena itu kedisiplinan adalah sikap seseorang yang menunjukkan ketaatan atau kepatuhan terhadap peraturan atau tata tertib yang telah ada dan dilakukan dengan senang hati atas kesadaran diri sendiri. Keteladanan dalam diri seseorang akan berpengaruh pada lingkungan sekitarnya, pada prinsipnya keteladanan seorang pimpinan akan mampu merubah prilaku pegawainya.

Penghargaan akan di berikan kepada pegawai yang memiliki prestasi dalam bekerja dan diusulkan kepada instansi terkait yang memberikan penghargaan. Selain itu juga mengusulkan promosi jabatan kepada pegawai yang di anggap mampu bekerja dan mempunyai disiplin kerja yang baik yang telah memenuhi persyaratan untuk menduduki jabatan yang lebih tinggi. Manfaat penghargaan yang di berikan kepada pegawai adalah untuk memotivasi pegawai dalam menjalankan tugasnya dan otomatis yang belum mendapatkan penghargaan akan termotivasi. Dengan demikian, pegawai merasa di hormati dan dihargai dengan mendapatkan penghargaan. Bentuk reward dan funishment selalu ada dalam organisasi seperti Kantor Camat Sungai Tebelian, ada reward berupa uang, kenaikan gaji berkala, kenaikan pangkat atau promosi jabatan serta ucapan terima kasih atau pujian dari pimpinan. Selain itu apabila staf memiliki kriteria kemampuan dalam bekerja, kemudian handal dalam bekerja, melaksanakan tugas yang diberikan oleh pimpinan dan dapat melaksanakan tugas dengan baik, perlu mendapatkan penghargaan.

Penghargaan itu penting karena dapat memberikan motivasi pada bawahan untuk bekerja lebih baik, hal ini juga mendukung untuk kemajuan dalam menjalankan tugas dan dapat menimbulkan semangat kerja. Selain itu agar pegawai memiliki kriteria, seperti memiliki kemampuan dalam bekerja, kemudian handal dalam bekerja, melaksanakan tugas dan pekerjaannya sesuai dengan pembagian tugas yang di berikan kepadanya. Selain itu motivasi bagi seorang pegawai akan meningkatkan kinerja sesuai dengan kemampuannya, karena itu akan menimbulkan gairah kerja bagi sesama pegawai sehingga pretasinya mendapatkan penghargaan dari pimpinan.

Pengarahan yang deberikan kepada pegawai dapat meningkatkan kedisplinannya 
dalam bekerja dan dalam pelayanan kepada masyarakat. Dengan demikian, pemberian penghargaan sebenarnya merupakan proses pembinaan kepada pegawai untuk mampu bekerja dan memberikan pelayanan yang terbaik sehingga masyarakat merasa puas dengan pelayanan yang diberikan. Oleh karena itu, pendidikan yang di berikan kepada pegawai untuk memberikan pengalaman sementara pelatihan bertujuan untuk meningkatkan keterampilan para pegawai. Dengan demikian, pekerjaan yang dilaksanakan para pegawai akan tercapai secara efektif dan efisien, maka pendidikan dan pelatihan memiliki peranan yang amat vital bagi kematangan kecerdasan bagi seorang pegawai. Sanksi di berikan sesuai dengan tingkat pelanggaran dan disesuaikan dengan aturan yang berlaku, sanksi berupa teguran lisan, bahkan tertulis diberikan dan tindak lanjut dari teguran ada beberapa pegawai yang di rotasi, mungkin keahlian pegawai tersebut kurang cocok dibidang tugas itu, dan memungkinkan di tempat yang baru akan bekerja lebih baik lagi sesuai dengan pendidikan dan latar belakang disiplin ilmu. Untuk sementara sanksi yang diberikan dalam bentuk teguran.

Pemberian sanksi kepada pegawai Kantor Camat Sungai Tebelian perlu dilakukan agar para pegawai Kantor Camat Sungai Tebelian dapat meningkat disiplin dalam melaksanakan tugasnya. Oleh karena itu yang berhak memberikan sanksi adalah seseorang pimpinan terutama pucuk pimpinan. Selanjutnya pemberian sanksi itu berjenjang apa bila staf yang melakukan pelanggaran maka atasan atau kasubsinya yang memberikan sanksi, dan apa bila kasubsi yang melakukan kesalahan atau pelanggaran, maka yang memberikan sanksi kepala seksinya. Namun apabila kepala seksinya yang melakukan pelanggaran maka kepala kantor yang memberikan sanksinya. Pegawai Kantor Camat Sungai Tebelian mengatakan bahwa sanksi yang diberikan oleh Pimpinan hanya berupa teguran, itupun melihat tingkat kesalahan yang dilakukan pegawai tersebut. Dengan adanya teguran dari Pimpinan sangat berpengaruh bagi pegawai dalam proses kegiatan organisasi.

Berdasarkan Peraturan Pemerintah Nomor 53 Tahun 2010 tentang disiplin Pegawai Negeri Sipil bahwa jenis hukuman disiplin terdiri dari hukuman disiplin ringan, hukuman disiplin sedang, hukuman disiplin berat. Setiap hukuman disiplin dijatuhkan oleh pejabat yang berwenang menghukum sesuai tata cara tersebut dalam peraturan disiplin pegawai negeri sipil. Pemberian saksi kepada para pegawai kantor Camat Sungai Tebelian sangat efektif, hal ini berdasarkan teguran dan pernyataan yang dilakukan oleh Pimpinan kepada pegawainya. Proses pemberian hukuman bagi pegawai negeri sipil yang melanggar kententuan, terdiri dari hukuman disiplin ringan, berupa teguran lisan, teguran tertulis, pernyataan tidak puas secara tertulis. Hukuman disiplin sedang, meliputi penundaaan kenaikan gaji berkala untuk masa sekurang-kurangnya 3 (tiga) bulan dan penurunan gaji sebesar satu kali kenaikan gaji berkala untuk masa sekurangkurangnya 3 (tiga) bulan, penundaan kenaikan pangkat untuk sekurang-kurangnya 6 (enam) bulan. Hukuman disiplin berat, terdiri atas penurunan pangkat pada pangkat yang satu tingkat lebih rendah untuk sekurang-kurangnya 6 (enam) bulan, pembebasan dari jabatan untuk masa sekurang-kurangnya selama 1 (satu) tahun, Pemberhentian dengan hormat tidak atas permintaan sendiri sebagai Pegawai Negeri Sipil, Pemberhentian tidak dengan hormat sebagai Pegawai Negeri Sipil.

\section{KESIMPULAN DAN SARAN}

Upaya Pimpinan dalam meningkatkan disiplin pegawai Kantor Camat Sungai Tebelian telah dilaksanakan melalui pengarahan, bimbingan, pengembangan pegawai melalui pendidikan dan latihan. Penegakkan aturan dan penegakkan tata tertib untuk meningkatkan disiplin pegawai Kantor Camat dalam 
menjalankan fungsi pelayanan publik. Selain itu penghargaan juga diberikan Pimpinan seperti memberikan tugas belajar, memberikan kesempatan kepada para pegawai Kantor Camat untuk mengikuti pendidikan dan latihan serta memberikan piagam penghargaan. Keteladanan Pimpinan sudah menunjukkan sikap seorang pimpinan, khususnya dilingkungan kerja di Kantor Camat, dengan adanya keteladanan akan memberi motivasi dan semangat kerja bagi para pegawai. Pemberian sanksi kepada para pegawai Kantor Camat yang kurang aktif masuk kantor hanya berupa

\section{DAFTAR PUSTAKA}

Amirin. 2000. Menyusun Rencana Penelitian. Jakarta: PT. Raja Grafindo Persada.

Departemen Pendidikan Nasional. 1998. Kamus Bahasa Indonesia Edisi Ketiga. Jakarta: Balai Pustaka

2001. Kamus Bahasa Indonesia

Edisi Ketiga. Jakarta: Balai Pustaka

Hasibuan, M. 1995. Organisasi dan Manajemen. Jakarta: Bumi Aksara. 2002. Manajemen Personalia dan Sumber Daya Manusia. Yogyakarta: BPFE.

Nawawi, H. 1995. Manajemen Sumberdaya Manusia, Gajahmada Universitas Press

. 2001. Manajemen Sumberdaya

Manusia. Yogyakarta: Gajahmada University Press. 2003. Metode Penelitian di Bidang

Sosial. Cet. 9. Yogyakarta : G a j a h m ad a University Press.

Prijodarminto, S. 1987. Disiplin Kiat Menuju Sukses. Jakarta: Pradnya Paramita . 2004. Disiplin Kiat Menuju Sukses. Jakarta: Pradnya Paramita

Saksono, S. 1997. Administrasi Kepegawaian. Jogjakarta: Kanisius.

Sastro Hadiwiryo.S.2001. Manajemen Tenaga Kerja Indonesia. Jakarta: PT. Bumi Aksara teguran dan sanksi tertulis berupa pernyataan yang dilakukan oleh Pimpinan dalam meningkatkan disiplin pegawai. Disarankan Kepada Pimpinan agar tetap meningkatkan disiplin kerja pegawai melalui pembinaan, penegakkan aturan dan pemberian penghargaan kepada pegawai yang memiliki prestasi baik di Kantor Camat Sungai Tebelian secara obyektif dan transparan. Selain itu pimpinan harus mempertahankan sikap yang baik, sehingga menjadi teladan dalam bekerja, dan dapat memberikan sanksi kepada pegawai Kantor Camat Sungai Tebelian yang tidak menjalankan tugasnya dengan baik.

Siagian, SP. 1983. Manajemen Sumberdaya Manusia. Jakarta : Bumi Aksara. . 1989. Manajemen Sumberdaya

Manusia. Jakarta : Bumi Aksara.

Yuk1, G.1992. Kepemimpinan Dalam Organisasi Leadership In Organization.

Terjemahan JusufUdayan. Jakarta: Prenhalin 1994. Kepemimpinan Dalam Organisasi Leadership In Organization.

Terjemahan Jusuf Udayana. Jakarta: Prenhalin 1998. Kepemimpinan Dalam

Organisasi Leadership In Organization.

Terjemahan Jusuf Udayana. Jakarta: Prenhalin

Peraturan Perundangan-Undangan:

Peraturan Pemerintah Nomor 41 Tahun 2007

Tentang Organisasi Perangkat Daerah. Tidak diterbitkan.

Peraturan Pemerintah Nomor 43 tahun 1999

Tentang Pokok-Pokok

Kepegawaian Republik Indonesia

Peraturan Pemerintah Nomor 53 tahun 2010

Tentang Disiplin Pegawai

Undang-Undang Nomor 5 Tahun 2004 Tentang Pokok-pokok Pemerintahan di Daerah (tidak diterbitkan)

Undang-Undang Nomor 32 Tahun 2004 tentang Pemerintah Daerah (tidak diterbitkan)

Undang -Undang Dasar Republik Indonesia Tahun 1945. 